OnLine Journal of Biological Sciences 9 (1): 1-5, 2009

ISSN 1608-4217

(C) 2009 Science Publications

\title{
Development of New Didactic Materials for Teaching Science and Biology: The Importance of the New Education Practices
}

\author{
Danon Clemes Cardoso, Maykon Passos Cristiano and Camila Orlandi Arent \\ Biological Sciences \\ University of Extreme South of the Santa Catarina-UNESC \\ Av. Universitária, 1105, Universitário, 88806-000 Criciúma-SC, Brazil
}

\begin{abstract}
Problem statement: The creativity of teachers in the planning process of their classes for teaching science and biology may be an instigator to promote and stimulate learning. The science should be something that awakens curiosity in students to make learning pleasurable and increase their interest. The aim this research was to develop didactic materials for to help the teaching-learning process in the content of science and biology. Especially, those content about systematic that can not be very exciting and bring some difficulty for the involvement of students. Approach: Inspired in the Atlantic forest, which extends along the Brazilian coast and offers a diverse ecosystem, were created some materials that enable the interaction of teacher with students, which were: "memory of the Atlantic forest", "unmasking the Atlantic forest" and a "set of transparencies". The first is composed of 25 cards each containing an image of a species of fauna or flora of the Atlantic forest, popular and scientific name. Complete the material, 25 letters with specific characteristics of each species. The second is a panel with the illustration of the incompleteness of the Atlantic forest ecosystem, featuring 10 pictures of animals that are hidden between the two sides of the panel and asked for 10 letters, which were answered to complete the ecosystem. The third is a set of transparencies containing information on the Atlantic, maps and data on the fauna and flora. The latter should be used to perform a preliminary discussion on the biodiversity of the Atlantic. Results: Results showed that these materials facilitate learning, as well as linking images of known species with their respective characteristics, makes the class interesting by providing the effective interaction of the group. Conclusion/Recommendation: These materials were used and well accepted by students of the course of biological science in the classes of micro-teaching and for students from elementary school.
\end{abstract}

Key words: Atlantic forest, biological sciences, teaching-learning

\section{INTRODUCTION}

When you think the teaching-learning process, it is essential we discuss the actions that make the relationship effective. We can take as an example of teaching the efficient method of educating the research, very well handled by Moraes et al. ${ }^{[1]}$ points out that "where the student must produce something in class (text with forecasts, reasons, descriptions, analysis, synthesis, evaluation) or outside", thereby strengthening idea that to have the learning, we need the construction of knowledge.

Second Freire ${ }^{[2]}$, the teaching is to transfer knowledge, but create opportunities for its production or its construction. This leads us to reflect on new challenges for the use of effective educational methods and strategies. To approach the learning topic, $\mathrm{Neto}^{[3]}$ highlights that there are three main elements to acquire the know: Quality, quantity and time. If there is little time and opted for the quality, the result will be low quantity. If the option is the quantity, results in low quality. Thus, the author suggests that a choice must be made by conditions in the school program, thus emphasizing the importance of having a good plan that allows these conditions to achieve satisfactory results.

In the teaching of science and biology the didactic materials are fundamental tools in the teaching-learning process, being an important and viable alternative in schools of public school system. The use of these materials can help the student in the contextualization of knowledge, filling many gaps left during learning, facilitating the students to build their own conceptions

Corresponding Author: Danon Clemes Cardoso, Licenciado em Ciências Biológicas, Universidade do Extremo Sul Catarinense-UNESC. Av. Universitário, 1105, Universitário. Criciúma, Santa Catarina, Brazil 88806-000 
of scientific knowledge in relation to common knowledge, and the socialization of previous knowledge and their use for the construction of new designs more elaborate ${ }^{[4]}$.

The materials and particularly textbooks, are the main link of connection not only between the teacher and student, but also between what is called the purpose and effect, as they seek to translate the principles of a proposed curriculum - which is a translation of more general goals of education and a vision of science and technology - in content and activities that can be assimilated by students ${ }^{[5]}$.

In general, the textbooks used in Brazilian classrooms are prepared for the global reality for use in all regions of the country. However, the contents of education expressed through texts that are often far from reality and interests of students. Thus, the distance between the real life of students and the texts of textbooks may be the factor most relevant to the failure of public schools ${ }^{[6]}$. This is the main importance of the introduction of new educational practices: The contextualization. For the teaching-learning texts meet in full its role must be added to materials that exploit the knowledge of students and awakens interest, reflecting the reality of students using examples that can be easily understood by him, and involve several scientific concepts to the various subjects of their reality.

Therefore, the didactic materials are important and that their use helps the learning process, but for that we need that the teacher sets a goal, take a look most didactic possibilities and limitations to be aware that the material may present. These materials may be purely visual, such as posters, maps, pictures, specimens or more provocative and instigating and auditory or interactive, which is the most important because that means the students are involved in the teachinglearning process and not purely assimilating the content that the teacher provides ${ }^{[7]}$.

Because these several reasons, the aim this study is develop didactic materials for to help the teachinglearning process in the content of science and biology. Especially, those content about systematic that can not be very exciting and bring some difficulty for the involvement of students. Furthermore, we performed a preliminary presentation of these materials for students of the course of Biological Science in the classes of micro-teaching and for students from elementary school. This presentation served to evaluate the perceptions of students before the introduction of new approaches in teaching science and biology.

\section{MATERIALS AND METHODS}

Creation of new teaching materials: For the preparation of materials were mainly used scraps. Why opt for this type of material, in addition to the benefits of reuse of solid waste, obtained a good reduction in the cost of the project.

Inspired in the Atlantic Forest, which extends along the Brazilian coast and offers a diverse ecosystem, were created some materials that enable the interaction of teacher with students, which were: "memory of the Atlantic forest", "unmasking the Atlantic forest" and a set of transparencies (Fig. 1 and Table 1).

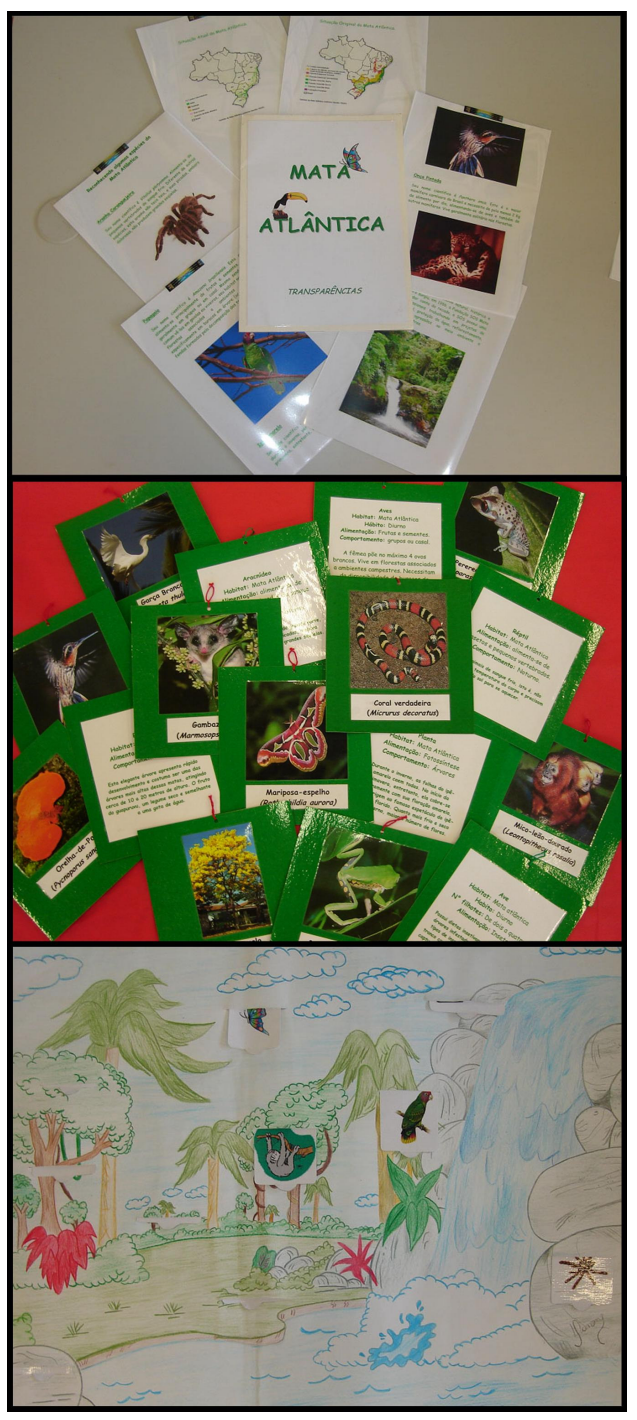

Fig. 1: The new teaching materials produced: "set of transparencies", "memory of the Atlantic forest "and "unmasking the Atlantic forest" 
Table 1: List of didactics materials and, continents, objectives and instructions

\begin{tabular}{ll}
\hline Didactic material & Continent \\
\hline Set of transparencies & $\begin{array}{l}\text { Slide 01 and 02-Text information about of ecosystem. } \\
\text { Slide 03-Map of Brazil locating and delineating the } \\
\text { formation of the original Atlantic forest. Slide 04-Map } \\
\text { of Brazil locating and delineating the formation of the } \\
\text { current Atlantic forest. Slice 05 and 06-Map of SC } \\
\text { locating and delineating the Atlantic forest in the Santa } \\
\text { Catarina state, actually and original. Slide 07-Flora and }\end{array}$ \\
& $\begin{array}{l}\text { Fauna of the Atlantic forest. } \\
\text { Game of the memory of the Atlantic forest is } \\
\text { composed of 50 letters and support from them. }\end{array}$
\end{tabular}

Unmasking the atlantic forest
Game of the Atlantic forest is composed of, 10 letters of questions the panel with rainforest ecosystem, with letters of hidden animals, a total of 10 animals
Objective

In that first moment the matter will be introduced, Atlantic forest, using the slides and projector.

Inform the endangered species that occur only in that ecosystem.

Instructions: The game has 25 cards with pictures of animals and plants and 25 with corresponding characteristics for each animal or plant in the support letters are hung on the buttons of a hand of cards with pictures and other features, and encouraged the child to turn a letter on each side, to characterize the settlement should be turning the figure of the animal with their characteristic.

Inform the child, the endangered species are endemic to this ecosystem, through the familiar design of the panel, the provision of the rainforest on the fauna and flora. Stimulate the intellect of the child, for training and a critical citizen. Directions: One and given the child, this letter contains a question or a statement, she with the help of the educator, must discover what the animal, and where he is in the Atlantic Forest. Attached, numbered panel on the location of the animals listed below with their numbers: 1-Crap spider, 2-Parrot, 3-Toucan,

4-Butterfly, 5-Sloth, 6-Snake, 7-Lizard, 8-Golden lion marmoset, 9-Woodpecker, 10-Jaguar

developed were tested on two occasions: First with students of graduation in biological sciences to assess the acceptability of these materials for future teachers. The acceptability of professionals related education is of essential importance, since it is one that depends on the implementation of new educational concepts and practices, to build the student's knowledge through curiosity. In a second time, the materials were brought to the classroom of fourth grade of elementary school (Fig. 2). This test aimed to evaluate the new materials inspired the curiosity of students and the student is brought to the interaction with the teacher.

\section{RESULTS}

The set of transparencies was used to perform a preliminary discussion on the biodiversity of the Atlantic. The material was well accepted by groups, students of Biological Sciences and the elementary school. Color images and the size of the font used contributed to the success of this approach to teaching. Moreover, the teachers keep the attention and urged the curiosity of students, main objective of the method.

In science class we can observe the effect of effective interaction between the students and teacher (Fig. 2). The participation of students was valuable. It was possible to observe clearly the interest and satisfaction of students and with the teacher.

\section{DISCUSSION}

The Brazilian education in public schools is structured as the student does not reach its potential as a whole. The poor recovery of professional education and sciences and elementary school: The new materials 
low investment in the school structure reflects the students who have low income school and disinterest in studies. Our public education also, neither facilitates access to learning. The learning in public schools is in teaching science, biology or geography, a mere repetition of old practices, the teacher speaking about something that is not to serve and which the student is asked to learn "what". Finally, the simple repetition you will be very little: the school as reproduction ${ }^{[8,9]}$.

Second Santa Catarina ${ }^{[10]}$, far beyond the curriculum, the social function of education in biology must be to help broaden the understanding that the individual has to their own biological organization, the place it occupies in nature and society, and the possibilities to interfere in the dynamics of these through a more collective action, aimed at improving quality of life.

The use of teaching materials in science classes is powerful tool for the development of the teachinglearning process through the construction of knowledge with the student. Mediating the consolidation of new concepts and demystify the science ${ }^{[11]}$. The Didactic material is often seen as a mediator between the aims of science and biology instruction and its outcomes. We can see clearly the impact of new methods of teaching on students. Demonstrating the need for new educational practices based on knowledge for the realization and improvement of education. The process of teaching and learning must be grounded in context, through the consolidation of scientific knowledge actually experienced by students, on the knowledge acquired in the common sense, toward the school contents $^{[12,13]}$.

To make such a challenge, we believe they should take into account some important aspects in the teaching-learning process as observe the student as a whole (their attitudes inside and outside the classroom, their hours of study, age, family responsibilities and social) observe and value the prior knowledge that each student brings, and their experiences, the good use the knowledge that the master has, not only in their area of training, but also in other areas as psychology and sociology ${ }^{[12]}$.

The school is the social space and place where the student will sequence to the process of socialization. What is it they say is valued and is an example of what the company wants and approves. Accordingly, we believe that if practiced environmentally correct behavior here is so productive that the school will contribute significantly to the formation of citizens committed to life, with the welfare of each individual and of society.

\section{CONCLUSION}

We found that these materials facilitate learning, as well as linking images of known species with their respective characteristics, makes the class interesting by providing the effective interaction of the group. These materials were used and well accepted by students of the course of Biological Science in the classes of microteaching and for students from elementary school. Our studies show that there is a great need for the implementation of new educational practices, even if simple, so that the schools effectively contribute to the formation of society.

\section{ACKNOWLEDGMENT}

We thank the M.L.M. Goularte and M.S. Campos (in memory) for helpful discussion and comment on this development this study. This research was partially produced during the Didactic for teaching science classes and was supported by the Brazilian research agencies CAPES and CNPq.

\section{REFERENCES}

1. Moraes, R., M.G. Ramos and M.C. Galiazzi, 2004. The Science of Learning in Education Research in the Sciences. In: Education in Science: Production of Curricula and Teacher Training, Moraes, R. and R. Mancuso (Eds.). Unijui, Ijuí, RS., ISBN: 8574294144, pp: 304.

2. Freire, P., 2003. Pedagogy of Autonomy. São Paulo, SP: Paz e Terra, ISBN: 9788577530151, pp: 148 .

3. Neto, A.C.S., 2004. Advances and challenges of the teaching-learning. Occupation master online. Classroom section. Curitiba. http://www.profissaomestre.com.br/smu/smu_vmat .php?s=501\&vm_idmat=832

4. Tarouca, M.R.L., M.L.P. Konrath, M.J.S. Carvalho and B.G. Ávila, 2006. Teacher training for production and use of objects of learning. New Technol. $\quad$ Educ., 4 1-10. http://www.cinted.ufrgs.br/renote/jul2006/artigosre note/a20_21173.pdf

5. Borges, G.L.A., 2000. Training teachers of biology, teaching materials and school knowledge. Ph.D. in Education. University of Campinas, Campinas.

http://libdigi.unicamp.br/document/?code=vtls0002 $20007 \backslash$

6. Silva, R.M., 2000. Didactic Texts: Criticism and Expectations.1st Edn., Alínea, ISBN: 8586491640, pp: 154. 
7. Gellert, U., 2004. Didactic material confronted with the concept of mathematical literacy. Educ. Stud. Math., 55: 163-179. DOI: 10.1023/B:EDUC.0000017693.32454.01

8. Pessanha, E.C., M.E.B. Daniel and M.A. Menegazzo, 2004. The history of school subjects to the history of the school culture: a history of research. Rev. Bras. Educ., 27: 57-69. DOI: 10.1590/S141324782004000300005

9. Son, L.M.F. and D.G. Vidal, 2000. The times and spaces in the process of institutionalizing children of primary school in Brazil. Rev. Bras. Educ., 14: 19-34.

http://redalyc.uaemex.mx/redalyc/pdf/275/27501403.pdf

10. Santa, C., 1998. Curriculum Proposal from Santa Catarina. Infant Education, Primary/Secondary Education: Curriculum Courses. State Department of Education and Sport. Florianópolis: COGEMA. pp: 244.

http://www.sed.sc.gov.br/index.php?option=com_d ocman\&task=doc_download\&gid=362
11. Cysneiros, P.G., 2004. Skills to teach with new technologies. Rev. Diálogo Educ., 4: 23-33. http://www2.pucpr.br/reol/index.php/DIALOGO?d $\mathrm{d} 1=54$

12. Cavalcanti, L.S., 2005. Cotidiano, mediation and educational training of concepts: A contribution of Vygotsky the teaching of geography. Cad. Cedes, 25: 185-207. http://www.cedes.unicamp.br

13. Zanette, E.M., E.R. Nicoleit and G.F.G. Nicoleit, 2006. The production of teaching material in the context of cooperative and collaborative discipline of differential and integral calculus $I$ in the form of distance education, on graduation. New Technol. Educ., 4: 1-9.

http://www.cinted.ufrgs.br/renote/jul2006/artigosre note/a33_21198.pdf 